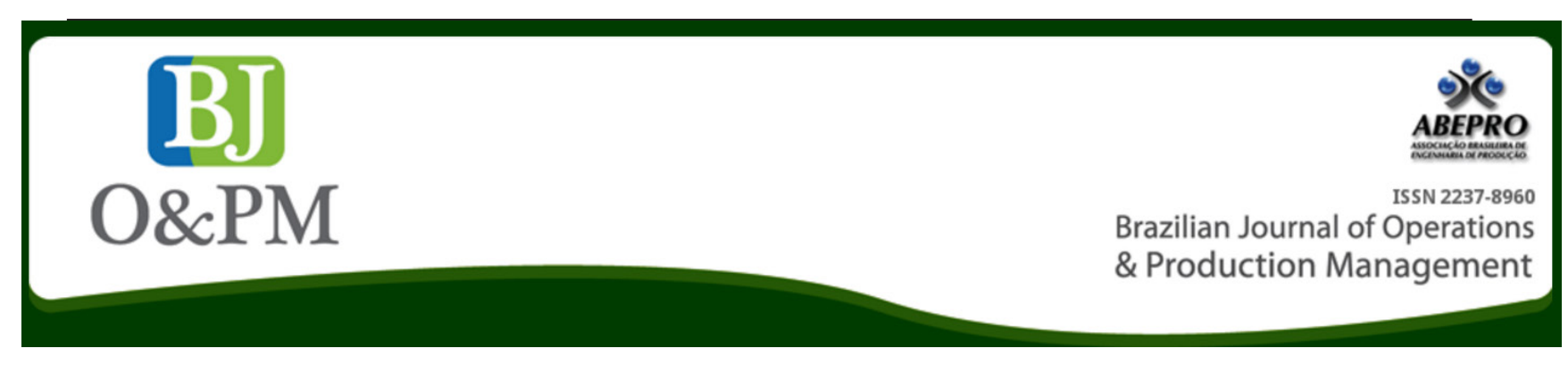

\title{
SALES PERFORMANCE MANAGEMENT: A STRATEGIC INITIATIVE TO THE GROWTH OF MICRO AND SMALL BUSINESSES
}

\author{
Evelyn Morais Galvãoa, Syntia Lemos Cotrima ${ }^{a}$, Gislaine Camila Lapasini Leal ${ }^{a}$, Franciely Velozo Aragãoa \\ a State University of Maringá (UEM) - Maringá, PR, Brazil
}

\begin{abstract}
Micro and small companies are lighting up in numbers and economic importance in the Brazilian market. In the sector of services, they already account for $27 \%$ of GDP. Given this importance, the purpose of this paper is to analyze how the integration of tools such as Planning Programming and Control of Production tools, together with the Quality Engineering tools such as performance management through indicators, can help to achieve the objectives of the organizations, especially small business, in the sales area. Boosting thus, strategically, these organizations to achieve and exceed their sales goals, become increasingly competitive, and growing in size and quality of service. The results obtained through the case study were satisfactory in 2014, where the signs of a crisis were already indicated in the country, this small business increased its sales by $12 \%$ compared to the year 2013.
\end{abstract}

Keywords: Performance Management; Quality Tools; Sales Strategy; Goals. 


\section{INTRODUCTION}

According to World Bank data (2013), the service sector has been increasing its participation in the economic growth of countries. It can be seen that in the year 2009, this sector accounted for $80 \%$ of French GDP and $71 \%$ of Germany's GDP in 2010. In Brazil, despite being a developing country, the contribution of this sector reached $67 \%$ of the national GDP in 2011.

Negri et Kubota (2006) points out that the services sector is of utmost importance with regard to the creation of companies and jobs in Brazil. According to the IBGE (2011), more than a third of national production $(36.3 \%)$ of the services sector come from small business. Since the micro and small enterprises in the country are growing and now account for $27 \%$ of its Gross Domestic Product (GDP).

However, according to Fontes et Pero (2009), the consolidation of institutions and the creation of favorable conditions for productivity increasing and the formalization of these business, are still a challenge for developing countries, such as Brazil's. What hinders the development of a model to increase access to markets.

To survive these challenges, it is essential that these companies know how to identify customer needs, so that they can determine strategic ways to reach sales targets while maintaining quality of service.

According to Kaplan (1940), "strategy is not an isolated management process; it is one of the steps in a logical continuum process that moves throughout the organization. "For Calvacanti (2007), every company must have a reason to exist; set goals that you want to achieve, and to achieving these goals is necessary to think more fragmented and strategic way.

This way, the strategy starts the discussion of issues related to threats, opportunities, risks and cares about customer's scopes, suppliers and competitors. From that point, plans and objectives are drawn for the organization to achieve its expected results.

Tubino (2006) points out that the current market has characteristics to be an increasingly globalized and competitive, all companies in both goods and services must adapt their production systems to improve continuously productivity in order to survive and remain competitive.

Ledingham et al. (2006), points out that an effective and efficient operation of a sales force is critical to the success of organizations. Thus, enhance sales can be an effective operational strategy to drive revenue and growth of profit. Accordingly, Lutif Junior et al. (2013) reported a performance management system and process development should be based on customer satisfaction, focusing on greater competitive advantage.
Therefore, this article aims to analyze how performance management can help as a strategic way to increase sales to small and micro enterprises, through the case study on a micro sales representative company of products for animal nutrition. The text is divided into four sections, besides this introduction. Section 2 presents the theoretical framework that supported the development of the proposal. Section 3 characterizes the research and describes the method adopted. In Section 4, the results are posted. Finally, in Section 5 presents the concluding remarks, highlighting the difficulties, limitations and future work.

\section{THEORETICAL FRAMEWORK}

\subsection{Demand Prevision}

According to Slack (2009), "without an estimate of future demand cannot plan effectively for future events, only reacting to them." Thus, the demand prediction is very important for the definition of a production system. Many organizations use demand prevision to plan their goals and strategies. Calôba et al. (2002) claim that companies exist to serve consumers with their products or services, thus forecast demand aims to assess the response of the end customer and plan measures to meet it in the most efficient manner.

Tubino (2007), points out that the demand prevision can be assessed using quantitative and qualitative methods, and serves as a basis for strategic planning in production levels, sales and finance. In addition, it is important to understand and correct interpretation of the data obtained and what were the technical bases and restrictions used to calculate demand, to facilitate communication between the PPCP and the Marketing sector. For Makridakis et al. (1998), determining the resources needed for an organization is accomplished through demand prevision. In addition, as the market changes constantly, it is necessary to demand previsions for shorter periods.

The demand prevision techniques are divided between quantitative and qualitative techniques, or even a mixture of both. Quantitative methods use historical data to forecast demand in future periods, and the qualitative use (Pellegrini et Fogliatto 2000; Werner et Ribeiro, 2003).

Qualitative techniques are based on the opinion and judgment of key individuals, specialists in products or markets where they operate these products, one of the best-known methods is the method of Delphi. Already quantitative techniques involve numerical analysis of past data, freeing up personal opinions or guesses. However, these techniques can also be employed in new products. They used mathematical models to project future demand. They can be subdivided into two major groups: the techniques based on time series, and the correlation-based techniques (Makridakis et al., 1998). 


\subsection{Quality Tools}

Ishikawa 1968 (cited Fernandes et Souza, 2013), states that $95 \%$ of quality problems can be solved through simple tools, such as the basic tools of quality. According to Paliska et al. (2007), the importance of using quality tools by both phases of product development, and in production can be highlighted, in order to reach the goal of reducing the production cost in addition to meeting customer satisfaction.

However, it is important to first diagnose what process needs priority of improvements implementation, helping with the justification for selection of one-of-ended process improvement. Miguel (2001) addresses some of the tools used in the research: Cause-effect diagram, Pareto chart, control chart and check sheet. The cause-effect diagram is a graphical tool that allows you to represent the causes of a problem (effect). According to Holanda et Pinto (2009), this tool can detect a large number of causes, for this fact, they can be divided into categories or families. The diagram should suit the situation studied and thus seek to relate what are the real causes.

The Pareto chart is based on Pareto's Law, which states that $80 \%$ of the effects are related with $20 \%$ of the causes. Campos (1999), points out that by Pareto analysis it is possible to obtain the stratification of the method into smaller problems and simple resolution, and assist in establishing concrete and achievable goals. The Control Chart, according to Miguel (2001), consists of a graph whose purpose is the monitoring of a process over a period of time, and monitoring under the variations of the calculated control limits and detection of the reasons of its variations. The check sheet for Aguiar (2002) aims to organize, simplify and optimize keeping the information of the registered collected data and in addition, the sheet can be adjusted depending on the type of information to be obtained from it.

\subsection{Indicators}

For Melnyk et al. (2004), performance measurement is a mean to connect the strategy to reality, the fact that no measurement strategy is useless, measurement without strategy makes no sense. According to Lima (2001) indicators promote a communication link between the performance of certain activities or actions, integrating the results and measures the goals set by the strategy. Rodrigues, Schuch et Pantaleão (2003) point out that the indicator systems are critical to direct actions of business improvement.

According to Carvalho et al. (2005), the indicators are defined in quantitative bases. These indicators are drawn from a logical composition, which evaluate two sets of information: its basic features and components that make up its structure. They must be precisely defined, and be understood by all, and are appropriate to the context to which they are being applied. Performance measurement aims to monitor the efficient use of available resources. The most common performance indicators are the productivity, return on investment, among others. Measure the performance of a factor, refers to not only plan, lead and manage, but also diagnosing the monitored environment (Martins, Neto Costa, 1998).

For De Toni et al. (1995), the offered quality is the result of position in the value chain, input (supplier quality and delivery performance), processing (quality performance of the product design, process engineering and manufacturing) and output (quality of sales performance and distribution), so the quality performance, refers to the performance of the entire value chain.

\section{RESEARCH METHOD}

This work is a case study with descriptive goals and nature of applied research, which proposes the identification and performance management through indicators, can help micro and small companies to act strategically to achieve its sales targets. Because, as stated by Carvalho et al.(2005) et Barbosa et Musetti (2011), the function of the indicators is to bring strategic thinking objectively to achieve certain results, allowing quantify the effectiveness and efficiency of action, and provide a critical analysis for improvement.

Therefore, in the research, the following steps were taken:

a) Determining a goal, which would become the indicator;

b) Historical sales data collection of the years 2012 and 2013 for the realization of a demand prevision;

c) Identification of the sales behavior trend in order to determine the growth prevision;

d) Line charts elaboration for study and analysis of the demand and projections.

e) Spreadsheet Implementation, with a field containing a check sheet for daily releases for generating graphic lines that have the purpose of tracking sales and comparison chart to reach the target set. There are also the indicators for follow-ups of two types of annual targets, divided monthly: one established by the company represented, and the other which was established by the representative.

\section{CASE STUDY}

The case study came from the strategic objective of the company A to overcome in 2014 sales set by the company B, which is represented by company $A$. Thus, it was necessary to search for techniques and tools that belong to the field 
of production engineering, as well as adapting them to the sales sector, so that the owner at least reach the target of company $\mathrm{B}$, and took action plans for the company $\mathrm{A}$ to reach its target. It was established the company $A$ for the year 2014, sales over 58,004 (fifty-eight thousand and four) thousand products, since the entrepreneur's growth target is to reach sales of 89,103 (eighty-nine thousand, one hundred three) thousand products, i.e., exceeding the target set in approaching alia $53.61 \%$.

The goals that Company B set its representatives are divided into three four-month periods, whose sales are equally divided over the four months each. Thus, the former has a smaller target; the second presents an aggressive target for being high-time sales and last an intermediate target. However, within each quarter there is no study of months may have low or high sales. In this context, to establish itself as the new goal would be achieved from Company A. First, the collection of historical sales data was conducted and analyzed graphically to understand the trend of sales, as shown in Figure 1 and Figure 2.

\section{Sales - 2012}
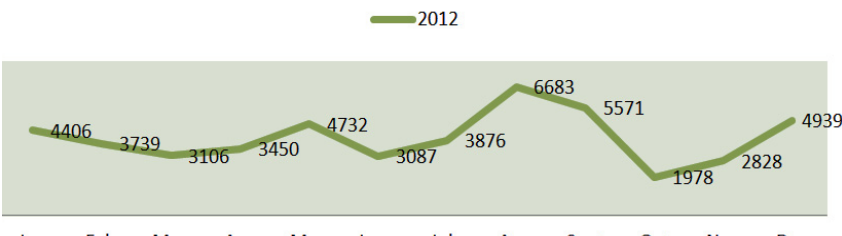

Jan Feb Mar Apr May June July Aug Sept Oct Nov Dec

Figure 1. Analysis of sales demand Graph 2012 Source: Author data (2014)

Sales - 2013

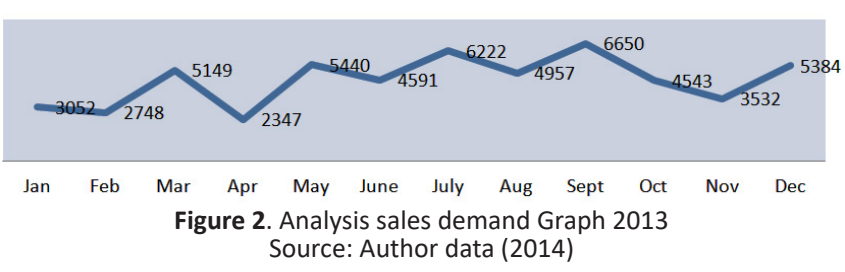

By analyzing the graphs of Figures 1 and 2 it was identified that there are some periods of high and low sales in common. For example, sales declines in February of both years, as well as in June and in the months of October and November. Similarly, it was also identified high in sales observed in the months of January, May and December. As a result, along the two graphs are plotted-for joint analysis of the data, as shown in Figure 3.

Through analysis of the chart shown in Figure 3, using the analysis of the Planning and Control Production Demand, it was concluded that the variations presented were not significant in sales, allowing the monthly demand of 2014 was calculated through the monthly average of the years 2012 and 2013, as shown in the graph of Figure 4.

\section{Comparative Sales: 2012 - 2013}

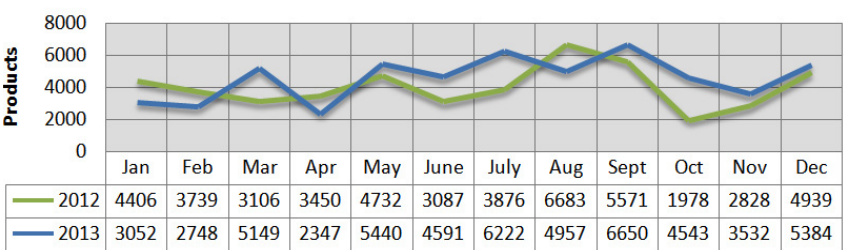

Figure 3. Sales comparison graph of years 2012 and 2013

Source: Author data (2014)

\section{Comparative Sales with Average: 2012-2013}

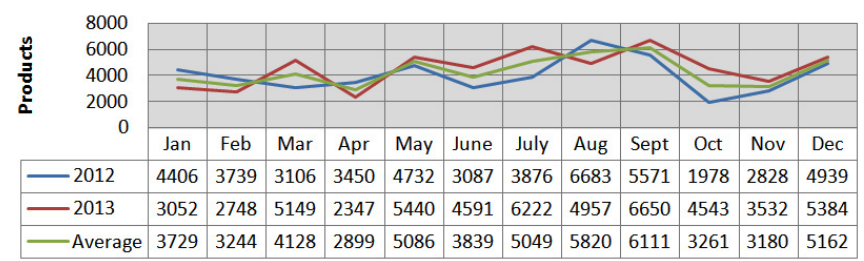

Figure 4. Comparison Chart of Sales in 2012 and 2013 with Average Source: Author data (2014)

As company $A$ has the goal of exceeding the target set by the company $B$, then it was analyzed the average annual sales of the years 2012 and 2013, so that it was found a basis for calculating the increase in percentage of sales, thus, based on the monthly variation of sales to new target was reached. Applying the percentage increase for each monthly demand in 2014, as shown in Figure 4, a graph was plotted to compare the projection for the year 2014 to the previous year, 2013. The projection shows how should be the volume sales for the year 2014 compared with the same periods last year, and is represented in Figure 5.

\section{Projection 2013 -2014}

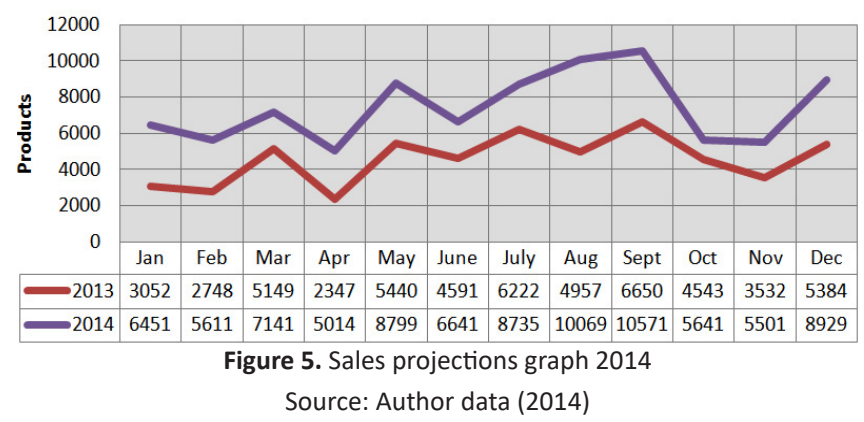

Therefore, the monthly demand has become the new goal to be sought, which in turn, was higher than that established by the company B. In other words, even if the company A's goals were not achieved immediately; they would serve as a way to boost it to increase the sales and could therefore make at least monthly goals set by the represented company met and / or even exceeded. Nevertheless, there would be a more accurate monitoring, and that generates a matter of urgency regarding the scope of these targets, integrated to the working tools of Quality Engineering Check Sheet and Performance Management through indicators. 
Thus, it was prepared a check sheet in a spreadsheet, with indicators, both were designed to measure the performance and get the comparative goals ranges, both of company $A$ (Figure 6-a), as the company B (Figure 6-b).

\begin{tabular}{|c|r|r|r|}
\hline January & \multicolumn{1}{|c|}{ See } & \multicolumn{2}{|c|}{ January } \\
\hline Goal & $\mathbf{6 4 5 1}$ & Goal & 4153 \\
\hline Real & $\mathbf{5 6 7 1}$ & Real & 5671 \\
\hline Lack & $\mathbf{7 8 0}$ & Performance & $137 \%$ \\
\hline Performance & $\mathbf{8 8 \%}$ & \multicolumn{2}{|}{} \\
\hline
\end{tabular}

(a)

(b)

Figure 6. Monthly monitoring indicator Model (representative company Goals)

Source: Author data (2014)

The field in the spreadsheet created from the beginning of the Check Sheet, is the responsibility of the company A which must feed the daily sales right out of the enterprise and the weekly sales of the outputs of the company B. And the sum of both outputs generates total sales in the end of the month that is compared to the target goals, both by the company representative and by the supplier.

From the data of the daily outputs of the company are generated two line charts, shown in Figure 6. One allows the tracking of changes in sales during the month and the monthly analysis of sales trends by the representative who may serve, future, to a new prevision demand. The other graph allows the comparison of the values set as a target, total sales to date and the remaining amount to achieve the sought goal. In this graph, it is expected that the character, which is the missing units to achieve the goal, touch or exceed the bottom axis of the chart, and the representative of the actual sales value character reaches or exceeds the representative of the target character.

The determination of the new sales targets and the creation of spreadsheet for monitoring indicators allow analysis to be made by check sheet and line chart generated by it, illustrated in Figure 7 . The analysis identified thed days of the week that the sales trend was higher compared to other days, or even days when sales were lower. Such as in the days of Monday and Wednesday the enterprise has sales peaks, as these have the lowest percentage below the monthly average of sales, representing $33.33 \%$ and $60 \%$, respectively. Likewise, if identified gaps, days that most weeks, there are considerable losses in the sales, for example, on Tuesdays and Thursdays, which have sales lower than the average corresponding to $80 \%$ and $75 \%$, respectively.

It is noteworthy that before the sales follow-up, these days of high and low sales were unknown until then by the company $A$, which is seeking new ways to turn this threat into an opportunity for the company. The results in 2014 were satisfactory, despite new goals have been achieved only twice a year, the first quarter, and the second in the last quarter, and was verified in 2014 there was a mid-range $71.5 \%$ of the target set by the company a and a total range of $5 \%$ of the targets set by the company $B$.

The graph in Figure 8 allows the analysis of performance between what was projected and actual sales reach through it already realizes the behavior of sales in 2014, allowing to see if the goals were or were not being met and analyze what is the difference between what was projected and the real scenario of sales.

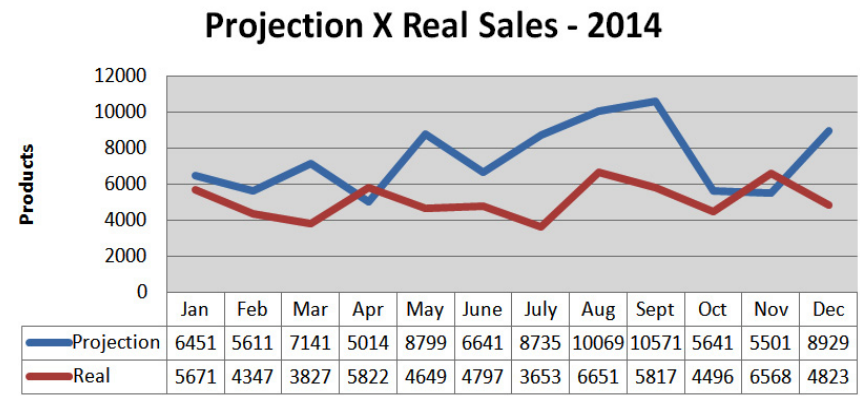

Figure 8. Accompanying chart Model for prevision and real sales 2014 Source: Author data (2014)

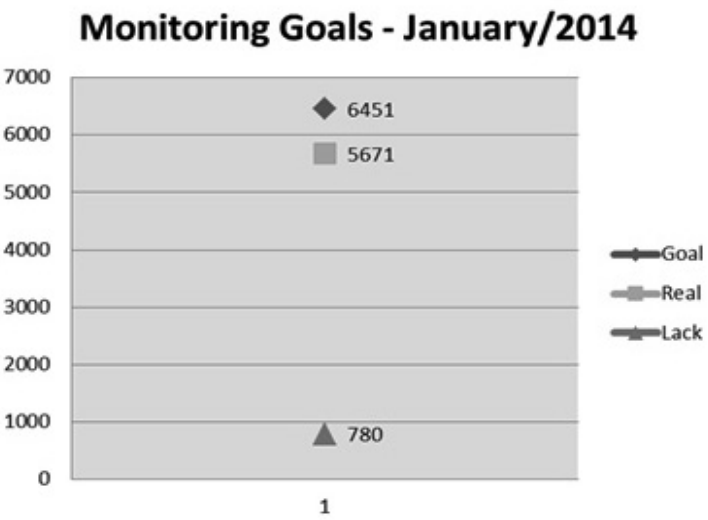

Figure 7. Accompanying chart model Source: Author data (2014) 
It can be observed in the months when the demand forecasting work by the representative began: January, February and April that they exceeded all sales of the same period in the years 2012 and 2013. Even, it is noteworthy that the month April was the only month in which the new goal for the first time was overcome reaching a range of $116 \%$. Only the month of March has not overcome the same month sales in 2013 , by the fact that, as was the prediction that one of the main inputs of the product to increase prices in March. Thus raising the price of the final product, there was a focus on these product sales that occurred before this elevation, i.e., in the month of February.

Compared to the second quarter, a drop in sales was noted, with the month of June the only month in which exceeded sales of the years 2012 and 2013, however it is noted there were fluctuations in overcoming months in 2014. They were higher in relation to one of the years studied. And the last semester showed framework similar to the second half, in which only the month of November exceeded sales of the years 2012 and 2013, and there are bounces in other months, in a few months in 2014 surpass the sales of the years compared.

Some reasons found with the help of a Brainstorming as responsible for sales of Company $A$, justified the cause of the drops in the months such as weather conditions in the Amazon region, more specifically in the region of Rondônia, where the company is active, which faced earlier this year a historical crowded on the state's major rivers, hampering the delivery of products to customers. In addition, because the rainy assist in pasture maintenance, reducing the need for consumption of animal nutrition products. Other main influence factors are large purchases by larger customers in a given month for storage of the product, or even leverage sales in periods when there is low value of the products offered.

\section{CONCLUSIONS}

In order to increase the enterprise sales, one can design the desired growth, meet the sales demand and its fluctuations on days when there are high or low sales. Based on this analysis, the company can better understand the process of service delivery and thus act strategically by increasing customer visits in the days when sales demand is lower. With the development of research, you can see the benefit of performance indicator in the service sector, highlight the difference between the determinations of a target, and not monitor it and its monitoring. Thus, in a simple and objective way, the performance management system provided greater urgency and let focus on finding ways of increasing sales, such as using Tuesday and Thursday to seek or visit new customers and/or potential.
The difficulty to get the job done is given due to climate changes in the region that influence the level of sales and the limitations of the company, which should be small, require preparation of action plans that do not adversely affect its operation. Since despite it be characterized as small size, it has the rigor of a larger company, such as hiring of skilled temporary workers for peak times, causing changes in the cost of the product. However, the act of seeking growth target and goal setting have been accompanied by the indicators helped to boost and overcome all the B Company goals in the first four months of 2014 by $18 \%$. The second quarter showed lower performance but reached $89 \%$ of what was proposed, and the last four sales rebounded again exceeding the target by $14 \%$.

Regarding the given target by the company $A$, as a very aggressive goal, the company reached about $69 \%$. Despite not having obtained the desired result, it can best meet its service sector, accompany it more judiciously, and even with signs of a possible financial crisis for the year 2015 in Brazil, it was possible to overcome the target set by the company B in 2014 by $5 \%$. Therefore, it has been clearly applied the benefit of using indicators that serve the purpose of directing the organization to set priorities, meet the terms established by them and together generate emergency character to situations and consequently bringing improvement and quality to the processes by means the action plans that are drawn and applied. In addition, the prospect is that for the years the use of indicators will become part of the organizational culture of the company, allow the analysis of demand, future projections, and search for new targets.

\section{REFERENCES}

Aguiar, S. (2002), Integração das Ferramentas da Qualidade ao PDCA e ao Programa Seis Sigma. Belo Horizonte: Editora de Desenvolvimento Gerencial.

Calôba, G. M., Calôba, L. P. et Saliby, E. (2002), "Cooperação entre redes neurais artificiais e técnicas 'clássicas' para previsão de demanda de uma série de vendas de cerveja na Austrália". Pesquisa Operacional, v.22, n.3, p.345-358.

Calvacanti, M. (2007), Gestão estratégica de negócios: evolução, cenário, diagnóstico e ação. 2.ed. rev. e amp. São Paulo: Thomson Learning.

Campos, V. F. (1999), TQC - Controle da Qualidade Total (no estilo japonês). 8.ed. Belo Horizonte, MG: Editora de Desenvolvimento Gerencial.

Carvalho, M. M. et al. (2005), Gestão da qualidade: teoria e casos, 4a reimp. Rio de Janeiro: Elsevier.

De Negri, J. A. et Kubota, L. C. (2006), Estrutura e dinâmica do setor de serviços no Brasil, Ipea. 
D Brazilian Journal of Operations \& Production Management Volume 14, Número 1, 2017, pp. 118-124 DOI: 10.14488/BJOPM.2017.v14.n1.a13

De Toni, A.; Nassimbeni, G. et Tonchia, S. (1995) "An instrument for quality performance measurement." International Journal of Production Economics, v.38, p.199207.

Fernandes, F. A.; Sousa, S. D. et Lopes, I. (2013), "On the Use of Quality Tools: A Cse Study". In: Proceedings of the World Congress on Engineering 2013 Vol I, WCE, July 3 - 5, London, U.K.

Fontes, A. et Pero, V. (2009), "Determinantes do desempenho dos microempreendedores no Brasil". Seminário de Pesquisa, IE/UFRJ. Available in: <http:// www.ie.ufrj.br/datacenterie/pdfs/seminarios/pesquisa/ texto0906.pdf>. Accessed: 19 Feb 2015.

Paliska, G., Pavletic, D. et Sokovic, M. (2007), "Quality Tools - Systematic use in process industry", Journal of Achievements in Materials and Manufacturing Engineering, November 25(1), pp. 79-82.

Holanda, M. A. et Pinto, A. C. B. R. F. (2009), “Utilização do Diagrama de Ishikawa e Brainstorming Para Solução de um Problema de Assertividade de Estoque em uma Indústria da Região Metropolitana de Recife". Anais do XXIX Encontro Nacional de Engenharia de Produção - Salvador. Available in: <http://www.abepro.org.br/biblioteca/enegep2009_ TN_STO_103_685_13053.pdf> Accessed: 13 abr.

Hisano Barbosa, D., et Andreotti Musetti, M. (2011), "The use of performance measurement system in logistics change process: Proposal of a guide". International Journal of Productivity and Performance Management, 60(4), 339359.

Kaplan, R. S. (2004), Mapas estratégicos - Balanced Scorecard: convertendo ativos intangíveis em resultados tangíveis. 8a reimp. Rio de Janeiro: Elsevier.

Lima, O. F. J. (2001), Análise e avaliação do desempenho dos serviços de transporte de carga. In: Caixeta-Filho, J. V. e R. S. Martins (eds.) Gestão logística do transporte de cargas. Ed. Atlas, São Paulo.

Lufit Junior, Q., Hékis, Q. et Lima, F. (2013), “Management non-profit organizations: an assessment of performance through the balanced scorecard". Brazilian Journal of Operations \& Production Management Volume 10, Number 2, pp. 57-66.

Makridakis, S.; Wheelwright, S. et Hyndman, R. J. (1998), Forecasting methods and applications. 3. ed. New York: John Wiley \& Sons.

Melnick, S., Steward, D. et Swink. M. (2004), “Metrics and performance measurements in operations management: dealing with the metrics maze". Journal of Operations Management, 22, p. 219-217.
Miguel, P. A. C. (2001), Qualidade: enfoques e ferramentas. São Paulo: Artliber Editora.

Pellegrini, F. R. et Fogliatto, F. (2000), “Estudo comparativo entre modelos de Winters e de Box-Jenkins para a previsão de demanda sazonal". Revista Produto \& Produção, v. 4, número especial, p. 72-85.

Rodrigues, L. H., Schuch, C. et Pantaleão, L. H. (2003), "Uma abordagem para construção de sistemas de indicadores alinhando a teoria das restrições e o Balanced Scorecard". Encontro da Associação Nacional dos Programas de Pós-Graduação em Administração, 27.

Slack, N., Chambers, S. et Johnston, R. (2009), Administração da Produção. 3.ed. São Paulo: Atlas.

Tubino, D. F. (2007), Planejamento e controle da produção: teoria e prática. São Paulo: Atlas.

Werner et Ribeiro (2003), "Previsão de Demanda: Uma Aplicação dos Modelos Box-Jenkins na área de assistência técnica de computadores pessoais". Gestão \& Produção, v.10, n.1, p.47-67.

World Bank (2008), Available in: <http://databank. worldbank.org/data/home.aspx\#>. Accessed: 20 jun. 2015. 